\title{
THE RELATIONSHIP BETWEEN ORGANISATIONAL CLIMATE AND SALUTOGENIC FUNCTIONING
}

\author{
F CILLIERS \\ S KOSSUTH \\ Department of Industrial Psychology \\ Unisa
}

\begin{abstract}
Organisational climate, defined as psychological atmosphere, was measured by means of 14 climate and four managerial support dimensions. Salutogenic functioning, referring to the origins of psychological health, was measured as the constructs sense of coherence, self-efficacy and locus of control. A representative sample of 245 mining personnel was used. Climate correlates significantly with sense of coherence and locus of control, and through these, with self-efficacy. It is recommended that Industrial Psychologists can act as facilitators in improving organisational climate by monitoring and enhancing the level of salutogenic functioning amongst its managers and staff members.
\end{abstract}

\section{OPSOMMING}

\begin{abstract}
Organisasieklimaat, gedefinieer as psigologiese atmosfeer, is gemeet deur middel van 14 klimaats- en vier bestuurs-ondersteuningsdimensies. Salutogeniese funksionering, wat verwys na die oorsprong van psigologiese gesondheid, is gemeet as die konstrukte sin vir koherensie, selfgenoegsaamheid en lokus van kontrole. 'n Verteenwoordigende steekproef van 245 mynpersoneel is gebruik. Klimaat korreleer beduidend met sin vir koherensie en lokus van kontrole en hierdeur, met selfgenoegsaamheid. Daar word aanbeveel dat Bedryfsielkundiges as fasiliteerders kan optree in die verbetering van organisasieklimaat, deur die vlak van salutogeniese funksionering by bestuurders en personeel te monitor en te verhoog.
\end{abstract}

Research results increasingly prove the relationship between salutogenic (Strümpfer, 1990) and fortigenic functioning (Strümpfer, 1992) on the one hand and various individual and work related behavioural constructs on the other hand. This can be seen as part of the challenge to explicate psychological well-being (see Wissing \& Van Eeden, 1994, 1997a, 1997b) within the field of positive psychology (Kogan, 2001), thus increasing knowledge about individual optimal functioning as well as organisational effectiveness.

Strümpfer and Wissing (1999) give a summary of such results, referring mostly to sense of coherence as the most widely recognised salutogenic construct and its measurement by means of the Orientation to Life Questionnaire (Antonovsky, 1987a). Examples of correlating individual constructs are cognitive style, anxiety, depression (see Schnyder, Büchi, Sensky \& Klaghofer, 2000), stress, positive / negative affectivity, neuroticism, self-esteem, sex role, life satisfaction, extraversion, independence, conscientiousness, agreeableness, role behaviour and power. According to Antonovsky (1987a) salutogenesis also provides a theoretical model for the analysis of work related behavioural constructs such as job security, involvement, commitment, power, change (Antonovsky, 1987b) and especially job satisfaction, which has been researched extensively from this paradigm (Rothmann, 2000; Strümpfer, 1998). Moving from the level of individual behaviour as seen from a systems viewpoint (Robbins, 1998) to the group / team level, there is little evidence of a relationship between salutogenic functioning and collective behaviour such as organisational climate. Research within the fields of clinical and family psychology (Feigin, Moshe \& Abraham, 1996; Sagy \& Antonovsky, 1998) provides some evidence of the role of salutogenic functioning within specific small group settings such as a family.

Although organisational climate has been defined in many different ways (Litwin \& Stringer, 1968), there seems to be consensus that it includes three behavioural levels, namely the individual, the interpersonal and the organisational. The individual's frame of reference influences his/her perception of the nature of the climate. Argued from the salutogenic paradigm and the study of coping behaviour (Antonovsky, 1979, 1987a), it could be hypothesised that the salutogenic person

Requests for copies should be addressed to: F Cilliers, Department of Industrial Psychology, UNISA, POBox 392 Pretoria, 0003
(Viviers, 1999) with his/her positive way of cognitively and effectively appraising the world, will be more likely to show "a readiness and willingness to exploit the resources ... at their potential disposal" (Antonovsky, 1984:21) in perceiving and influencing organisational climate. This is especially important in the South African mining industry, where the quest for establishing a motivated and committed work force to cope with the increasing demands for survival and change (and its effect on climate), is threatening the industry's survival as well as the country's economic welfare. Therefore, the focus in this research is not whether organisational climate is positive, productive and growth enriching, but rather how the existing climate is perceived by the individual employee with reference to his/her salutogenic functioning.

\section{Organisational climate}

On the meta-level, climate refers to the organisation's psychological atmosphere (Kline \& Boyd, 1991; Lewin, 1951; Prakasam, 1986), and on the operational level climate consists of organisational, interpersonal and individual dimensions (Gelfand, 1972; Likert, 1961; Litwin \& Stringer, 1968; Prakasam, 1986; Taguiri \& Litwin, 1968).

Organisational dimensions on the formal level, are structure, policy, objectives, management practice, task specialisation, decision making, standard and reward. On the informal level, it refers to identity, employee needs, responsibility, interactive communication, information sharing, support, warmth and conflict handling (Kline \& Boyd, 1991; Likert, 1961; Litwin \& Stringer, 1968; Prakasam, 1986; Taguiri \& Litwin, 1968).

The interpersonal dimensions refer to the nature of managerial support with its directive and interactive properties. The directive one's are structure, role clarity, job standards, managerial effectiveness and job satisfaction and the interactive one's are communication, team functioning, contribution to profits, conflict handling and reward. The combined directive / interactive properties are responsibility, decision making, job tension and propensity to leave (Kline \& Boyd, 1991; Prakasam, 1986). Managerial support forms part of an effective goalsetting strategy (Vance \& Colella, 1990) and impacts on goal acceptance, goal commitment and performance (Locke, Shaw, Saari \& Latham 1981). It can be defined as a positive, constructive and helpful attitude of the manager towards subordinates 
in the attainment of goals (Locke \& Latham, 1984). Babin and Boles (1996) suggest that support is measured by the provision of key resources (equipment and training), which facilitate the performance of the employee. Cummins (1989) suggests that managerial support relates to the building of the esteem of each employee, through informal and problem solving support. Based on House's (1981) concept of interpersonal transaction, managerial support consists of information support (information about the job), appraisal support (assistance in setting objectives), instrumental support (assistance with resources) and emotional support (a caring attitude).

The individual employee's frame of reference influences his/ her perception of the nature of organisational climate (Burke \& Litwin, 1992; Day \& Bedeian, 1991). Thus, organisational climate results from the way in which the above organisational dimensions are managed (Collins, Davis, Myers \& Silk, 1964; Litwin \& Stringer, 1968), the quality of the manager's leadership style (Fiorelli \& Margolis; 1993; Kottke \& Sharafinski, 1988; Sorensen \& Savage, 1989) as well as the way the individual perceives and reacts to the atmosphere (Bandura, 1982; Carrol \& Tosi, 1970; Constable \& Russell, 1986; Latham \& Saari, 1979; Pretorius, 1993; Winnbust, Marcelissen \& Kleber, 1982). This literature assumes that a positive interaction between all of the above will result in improved work performance.

\section{Salutogenic functioning}

The salutogenic paradigm (Antonovsky, 1979; 1984; 1987a) focuses on the origins of health and wellness, the location and development of personal and social resources and adaptive tendencies which relate to the individual's disposition, allowing him/her to select appropriate strategies to deal with confronting stressors. Antonovsky (in Cooper \& Payne, 1991) suggests using the sense of coherence, self-efficacy (Bandura, 1989) and locus of control (Rotter, 1990) as the most important constructs in salutogenic functioning - as used in research by Kossuth (1998), Rothmann (2000) and Viviers (1996).

1. Sense of coherence (SOC). Antonovsky (1984; 1987a) defines the SOC as a global orientation that expresses the extent to which the individual has a pervasive, enduring, though dynamic feeling of coherence, that (1) the stimuli deriving from his/ her internal and external environments in the course of living are structured, predictable, and explicable; (2) the resources are available to meet the demands posed by these stimuli; and (3) these demands are challenges worthy of investment and engagement. The SOC predicts the extent to which the individual feels that there is a probability that things will work out well (Antonovsky, 1979). It consists of three core personality characteristics, namely comprehensibility (making sense of the stimuli in the environment), manageability (coping with the stimuli in view of the available resources) and meaningfulness (an emotional identification with events in the environment). The strength of the SOC is connected to a variety of coping mechanisms, called generalised resistance resources (GRR's) (Antonovsky, 1979), defined as any characteristic of the person, the group, or the environment that can facilitate effective tension management. According to Antonovsky (1987b), work has a significant role to play in the shaping of the SOC. A work environment which is predictable, manageable, where the employee can participate in decision making and has a voice in regulating his/ her work, enhances the SOC because work is experienced as meaningful. Strümpfer (1995) supports this notion by saying that if all aspects are equal, the above orientation to work can only lead to productive performance, recognition, reward and promotion. These experiences would then become work-related GRR's that will strengthen the SOC further.

2. Self-efficacy. Developed within the broad framework of social (Bandura, 1989; Kirsch, 1986) and cognitive learning theory (Gist \& Mitchell, 1992), self-efficacy focuses on the dynamic, triadic, reciprocal, causation relationship between cognition, behaviour and the environment. It refers to the individual's belief that he/ she has the capabilities to mobilise the motivational and cognitive resources, and courses of action needed to meet given situation-demands (Bandura, 1997; Wood \& Bandura, 1989). The individual sets high, challenging and achievable goals, shows commitment and exercises choice and control over events in his/her life, which stimulates more success (Gist \& Mitchell, 1992; Kirsch, 1986). A responsive, encouraging and rewarding environment, valuing aspirations, engagement and accomplishments, stimulates self-efficacy further (Bandura, 1997; Barling \& Beattie, 1983; Lee, 1988; Taylor, Locke, Lee \& Gist, 1984).

3. Locus of control (LOC). Attributed to Rotter (1966), this concept derives from social learning theory with its focus on reinforcement in the acquisition of knowledge and skills. LOC is defined as the extent to which the individual perceives that he/she has control over a given situation (Sutherland \& Cooper, 1990). The differentiation between external and internal LOC lies in the experience of freedom (Antonovsky in Cooper \& Payne, 1991), attribution and cognitive performance (Rotter, 1966). The external individual feels out of control, sees no relationship between own behaviour and events, attributes the cause of events to the environment, others and fate, feels anxious, frustrated and helpless. The internal individual feels in control, sees a relationship between own behaviour and outcomes, attributes the cause of events to themselves, feels empowered and masterful and thus experiences less stress. Cognitively the internal acquires larger amounts and more diverse kinds of information. Work-wise, the external perceives performance as dependent on incentives, and believes that the withdrawal of these will lead to a loss in production (Erwee \& Pottas, 1982). The internal perceives his/her own skill and judgement as a means to solving problems, and success not as entirely dependent on the existence or non existence of incentives (Garson \& Stanwyck, 1997). He/she attends more to own self-development, shows more initiative, develops more constructive relationships with subordinates, is more participative, enterprising and achieves better results than an external (Foley \& Clifton, 1990, Payne \& Manning, 1988).

The salutogenic personality profile incorporates the following behaviour ( Viviers, 1999): On the cognitive level, the individual is able to view stimuli from the environment in a positive and constructive manner, and to use the information towards effective decision making. On the affective level, the individual functions with self-awareness, is confident, self-fulfilled, views stimuli as meaningful and feels committed towards life in a mature manner. On the conative level, the individual has internal motivation, perceives stimuli as a challenge which directs his/her energy to cope, solve problems and achieve results. The interpersonal characteristics entail the capacity to form meaningful relationships with others at work and in society.

\section{Theoretical integration}

In linking work behaviour to sense of coherence, Antonovsky (1987b) refers to the experience of consistency providing a basis for comprehensibility, strengthening it further when the work environment enables the individual to see the entire spectrum and his/her own role in it. It also fosters confidence and feelings of security and it supports communicability in social relationships. A balance in workload provides a basis for manageability, strengthening it further in the case of collective decision making because perceived social resources, such as the support and advice of superiors and colleagues, are instrumental in the well-being of the individual. Participation in decision-making provides a basis for meaningfulness.

Feldt, Kinnenen and Mauno (2000) found a strong relationship between SOC and organisational climate - employees who perceived organisational climate as positive and job security as high, reported higher scores on SOC. A positive climate has a strengthening effect on an individual's view of the environment as being meaningful. They also found that when climate worsened, SOC diminished. SOC is high where the climate is considered to be positive within families (Antonovsky, 1988) and amongst university staff members (Ryland \& Greenfeld, 1992). The same applies where the climate is seen as contributing to the experience of meaning in and regard for life (Auhagen, 2000). 
Self-efficacy is high in organisations with effective human resources policies and practices, where the culture is stimulating empowerment amongst employees (Chiles \& Zorn, 1995), where decision making and performance are effective and the attaining of set management goals takes place (Bandura \& Wood, 1989; Wood \& Bandura, 1989). Similar findings were reported in terms of internal locus of control (Rotter, 1966; 1990).

The above literature suggests that the high level salutogenic functioning employee perceives and assesses organisational climate in an optimistic and positive manner, understands the nature thereof and it will make sense to him/her. He/she feels involved and commitment towards climate issues and takes responsibility for his/her own behaviour and contribution therein. He/she believes in own abilities and acts from an internal motivation in influencing climate to the better, depending on a positive and supportive interpersonal environment.

\section{Aim and research design}

The aim of this research is to determine whether a relationship exists between organisational climate and salutogenic functioning and to report on the nature thereof. A quantitative survey design is used, measuring the two variables and reporting on the statistical correlation between them.

\section{METHOD}

\section{Population and sample}

The research was done in the coal mining industry within one group of companies in Mpumalanga. The population consists of employees within one operation consisting of the mining, engineering, metallurgy, technical services, finance, administration, human resources and security disciplines. From this, a representative sample of $245(45 \%)$ was drawn. The sample consisted of $13(5 \%)$ mine managers (Patterson band E), 39 $(16 \%)$ senior supervisors (band D) and 193 (79\%) artisans, miners, foremen and supervisors (band C). All were male $64 \%$ white and $36 \%$ black.

\section{Measuring Instruments}

The following five instruments were used:

1. The Organisational Climate Questionnaire (Prakasam, 1986) measuring 14 climate dimensions. 2. The Managerial Support Questionnaire, incorporating House's (1981) dimensions of support and the Ballantine, Nunns and Brown (1992) supervisory support scale, measuring 4 support dimensions. 3. The Orientation to Life Questionnaire (Antonovsky, 1987a), giving a total score for SOC and sub scores for comprehension, manageability and meaningfulness (Antonovsky, 1993). 4. The Selfefficacy Questionnaire (Tipton \& Worthington, 1984) (a unidimensional instrument). 5. The Locus of Control Questionnaire (Rotter, 1975) (a uni-dimensional instrument) (Ferguson, 1993; Rotter, 1966).

Acceptable levels of reliability and validity on both the climate instruments are reported by Kossuth (1998) and on all three the salutogenic instruments by Kossuth (1998), Rothmann and Venter (2000), and Viviers (1996). These instruments were chosen because of their psychometric qualities as well as their conceptual correspondence with the above definitions and behavioural characteristics of the constructs.

\section{Data collection}

The measuring instruments were computerised (in English and Afrikaans) and the sample was invited to attend pre-arranged sessions in groups of 30 in a computer room. The administration was done by a psychologist, trained and in command of the appropriate computer software. Each session lasted approximately two hours. The computerisation made it possible to ensure that all respondents answered all items on the measuring instruments.

\section{Data processing and hypothesis}

The following statistical analysis was done by means of the SAS (1985) and SPSS (1994) computer packages.
1. Reliability and dimensions of the measuring instruments. The data for each of the five measuring instruments were analysed separately, in terms of item-test reliability and Cronbach alpha's. As guideline, the suggestions by Watkins and Mauer (1994) (item-test correlations of less than 0,2 should be excluded) and Nunnally (1978) (an item of between 0,5 and 0,6 is satisfactory for research purposes) were used.

2. Inter correlations. The strength of the relationship between the dimensions were calculated, using the Pearson-product moment correlation coefficient (Howell, 1989). The statistical hypothesis being tested is that there is a significant relationship between organisational climate and the salutogenic constructs.

\section{RESULTS}

Reliability and dimensions of the measuring instruments The Cronbach alpha's and final confirmed dimensions for the five instruments were as follows: For the organisational dimensions, 0,86 / 14 dimensions; supervisory support, 0,96 / 4 dimensions; SOC, 0,85 / 4 dimensions; self-efficacy, 0,78 / 1 dimension; and for LOC, 0,65 / 1 dimension. This indicates that the measurement was reliable and that each instrument measures the dimensions as theoretically discussed above.

\section{Inter correlations}

Table 1 indicates strong correlations between the climate behaviours namely the 14 organisational and the four supervisory support dimensions. This corresponds with the findings of Lyons (1971) and Prakasam (1986).

TABLE 1

CORRELATIONS BETWEEN CLIMATE DIMENSIONS

\begin{tabular}{|c|c|c|c|c|}
\hline $\begin{array}{l}\text { ORGANISATIONAL } \\
\text { DIMENSIONS }\end{array}$ & \multicolumn{3}{|c|}{$\begin{array}{c}\text { SUPERVISORY SUPPORT } \\
\text { Information Appraisal Instrument }\end{array}$} & \multirow{2}{*}{$\begin{array}{r}\text { Emotional } \\
0,40 \star \star \star\end{array}$} \\
\hline 1 Decision making & $0,40 \star \star \star$ & $0,38 \star \star \star$ & $0,43 \star \star \star$ & \\
\hline 2 Job / org structure & $0,39 \star \star \star$ & $0,42 \star \star \star$ & $0,47 \star \star \star$ & $0,42^{\star \star \star}$ \\
\hline 3 Role clarity & $0,31 \star \star \star$ & $0,36 \star \star \star$ & $0,34 \star \star \star$ & $0,30 \star \star \star$ \\
\hline 4 Job standards & $0,33 \star \star \star$ & $0,44 \star \star \star$ & $0,36 \star \star \star$ & $0,34 \star \star \star$ \\
\hline 5 Conflict handling & $0,40 \star \star \star$ & $0,45^{\star \star \star}$ & $0,42 \star \star \star$ & $0,45^{\star \star \star}$ \\
\hline $6 \begin{array}{l}\text { Supervisor } \\
\text { effectiveness }\end{array}$ & $0,53 \star \star \star$ & $0,62^{\star \star \star}$ & $0,60 \star \star \star$ & $0,57 \star \star \star$ \\
\hline 7 Communication & $0,53 \star \star \star$ & $0,56 \star \star \star$ & $0,57 \star \star \star$ & $0,54 \star \star \star$ \\
\hline 8 Team building & $0,33 \star \star \star$ & $0,39 \star \star \star$ & $0,37 \star \star \star$ & $0,37 \star \star \star \star$ \\
\hline 9 Responsibility & $0,27 \star \star \star$ & $0,23 \star \star \star$ & $0,27 \star \star \star$ & $0,30 \star \star \star$ \\
\hline 10 Reward & $0,33 \star \star \star$ & $0,31 \star \star \star$ & $0,34 \star \star \star$ & $0,31 \star \star \star$ \\
\hline 11 Job satisfaction & $0,40 \star \star \star$ & $0,42 \star \star \star$ & $0,39 \star \star \star$ & $0,38 \star \star \star$ \\
\hline 12 Absence job tension & $0,23 \star \star$ & $0,22 \star \star \star$ & $0,27 \star \star$ & $0,26 \star \star \star$ \\
\hline 13 Propensity to leave & $0,43 \star \star \star$ & $0,43 \star \star \star$ & $0,45^{\star \star \star}$ & $0,43 \star \star \star$ \\
\hline 14 Contribution to profits & $0,46^{\star \star \star}$ & $0,51 \star \star \star$ & $0,47 \star \star \star$ & $0,44 \star \star \star$ \\
\hline
\end{tabular}

$\star \star \star \mathrm{p}<0,0001 \star \star \mathrm{p}<0,01$

Table 2 indicates strong correlations between the three salutogenic constructs, including the sub-scores of SOC. This corresponds with the findings by Viviers (1996) as well as Drory and Florian (1998).

TABLE 2

CORRELATIONS BETWEEN SALUTOGENIC CONSTRUCTS

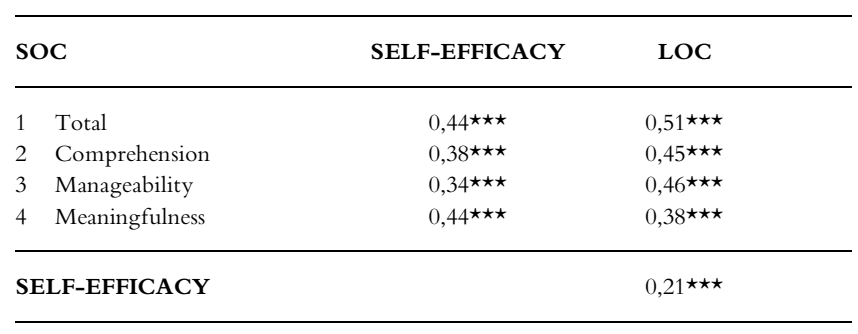

$\star \star \star \mathrm{p}<0,0001$

Table 3 indicates a strong relationship between the climate dimensions and the SOC's total score, as well as with most of the 
sub-scores. Five of the organisational and none of the supervisory support dimensions correlate with self-efficacy. All of the climate dimensions show a relationship with LOC.

TABLE 3

INTERCORRELATIONS BETWEEN CLIMATE DIMENSIONS AND SALUTOGENIC CONSTRUCTS

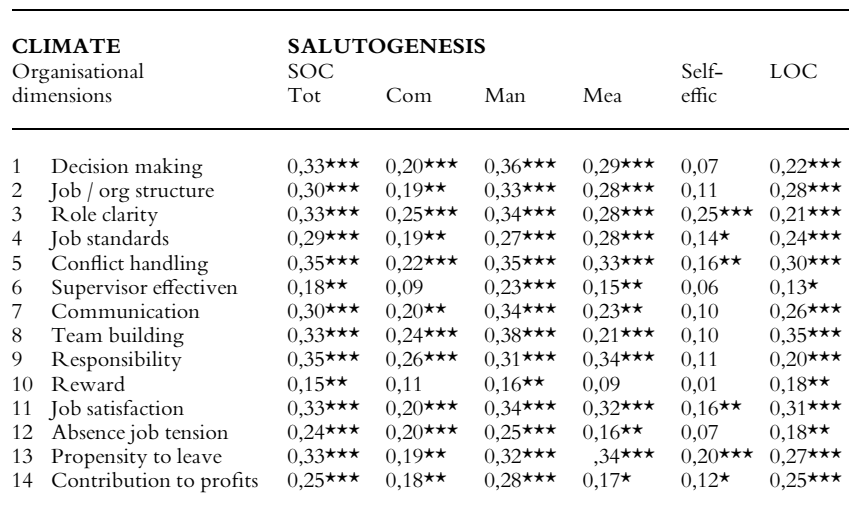

Supervisory support

\begin{tabular}{lllllll}
\hline Information & $0,19 \star \star$ & 0,10 & $0,26 \star \star \star$ & $0,14 \star \star$ & 0,01 & $0,18 \star \star \star$ \\
Appraisal & $0,19 \star \star$ & $0,12 \star \star$ & $0,21 \star \star \star$ & $0,15 \star \star$ & 0,02 & $0,17 \star \star$ \\
Instrument & $0,22 \star \star \star$ & $0,14 \star \star$ & $0,29 \star \star \star$ & $0,15 \star \star$ & 0,09 & $0,22 \star \star$ \\
Emotional & $0,23 \star \star \star$ & $0,14 \star \star$ & $0,28 \star \star \star$ & $0,17 \star \star$ & 0,02 & $0,22 \star \star \star$ \\
\hline
\end{tabular}

$\star \star \star \mathrm{p}<0,0001 \star \star \mathrm{p}<0,01 \star \mathrm{p}<0,05$

The results show a significant relationship between organisational climate and salutogenic functioning, specifically SOC and LOC.

Cognitive behaviour. The salutogenic functioning individual perceives the organisation as a coherent system in terms of its structure; sees climate in a positive light in terms of its structure, performance standards and opportunities for recognition and promotion; evaluates the effectiveness of decision making and understands why it is made on specific organisational levels; understands his/her own role in the organisation and knows how to perform effectively; experiences the self as effectively involved in decision making; accepts the responsibility being delegated to him/her; experiences job satisfaction and turns negative tension into a positive experience.

Affective behaviour. The individual experiences comfort with organisational planning as well as the level of order or chaos; feels recognised from within instead of easily criticised or punished, confident and comfortable to express ideas, free to receive constructive criticism, involved in the solving of disagreements and problems in a mature way; experiences a lack of suspicion and feels generally comfortable to stay on in the organisation.

Conative behaviour. The individual experiences the predictability of organisational life; engages in managing the demands through making use of own resources, skills and judgement; sees the relationship between own, team and organisational behaviour and outcomes; and empowers the self.

Interpersonal behaviour. The individual relies on and ensures having the necessary information from colleagues and supervisor; has confidence in the supervisor's abilities to set objective; is open to the supervisor's support and assistance in terms of information and resources; accepts emotional support and guidance form the supervisor; communicates freely; participates and gives constructive cooperation to make a group work as a team. He/she will be trusted by others to perform his/her assigned task and will contribute towards establishing a positive climate.

Further, the results show a significant relationship between organisational climate and salutogenic functioning, specifically self-efficacy, through the primary relationship and as well as through the inter-correlations between the salutogenic constructs, SOC, LOC and self-efficacy. Thus, the statistical hypothesis is accepted.

\section{DISCUSSION}

In line with the above theoretical expectation and hypothesis, the results revealed that the individual's experience of a positive organisational climate relates to a high level of salutogenic functioning. On the other hand, the perception that the organisational climate is negative, relates to a low level of salutogenic functioning. This research firstly supports Antonovsky's (1987b) observation that a comprehensive, manageable and meaningful (SOC) working environment relates to a positive psychological atmosphere. Secondly, the result adds self-efficacy as a cognitive / environmental disposition and self-efficacy and locus of control as representing an internal motivational stance, as relating to a positive experienced organisational climate.

Antonovsky (1987b) also claims that the two constructs have a strengthening effect on one another. It is suggested that a positive organisational climate strengthens the individual's experience of meaningfulness as the cognitive component as well as manageability as the motivational component (Antonovsky, 1987a; 1987b; 1993). This result adds the cognitive / environment disposition measured by self-efficacy to the already known comprehensibility and the internal locus of control measured by self-efficacy and locus of control, to the manageability aspect. On the other hand, this means that a working environment characterised by comprehensibility, individual belief and trust in own cognitive resources, manageability where the individual is internally motivated and emotional meaningfulness, will strengthen the organisational climate towards becoming more positive.

It may be worth mentioning the correspondence between the above findings about organisational climate and results with other situational organisational variables. Rothmann (2000) found a strong correlation between these same three salutogenic constructs and job satisfaction. Rothmann and Agathagelou (2000) found a correlation between internal locus of control (including autonomy) and job satisfaction.

Argued from the organisational climate point of view, the results suggest that almost all of the above organisational dimensions as well as the support given by the supervisor, impact on the individual's understanding of the bigger picture (comprehension), his/her ability to cope (manageability), and his/her emotional commitment to his/her work (meaningfulness). These dimensions also influence the amount of personal control and freedom the individual experiences and is able to exercise in his/her work, the realisation of the link between own behaviour and outcomes and the resulting empowered effect. The individual will be able to influence climate in terms of bringing in information as well as facilitating effective relationships amongst colleagues.

It is concluded firstly that organisational climate is significantly influenced by employee's salutogenic functioning. Firstly, a high SOC and LOC facilitates a more (than a low level) positive and realistic perception and effect on climate. This is supported by the individual's level of self-efficacy in a secondary way. Secondly, the nature of organisational climate influences the individual's salutogenic functioning, which could explain how, for example, a depressing climate can immobilise employees and vice versa.

In view of the findings, the following recommendations are made:

1. Future research projects on organisational climate should include more salutogenic constructs such as hardiness, learned resourcefulness, self-actualisation and emotional intelligence (see Viviers, 1999; Wissing \& Van Eeden, 1997b). 
2. The nature of the relationship indicates that Industrial Psychologists can facilitate improved organisational climate by using the level of salutogenic functioning amongst managers and staff members as indicator. This implies becoming more aware of their level of cognitive understanding of stimuli in a positive and constructive manner, their level of experienced meaningfulness, internal motivation and the quality of their interpersonal relationships. This will act as mirror of the collective psychological atmosphere amongst the team and even in the larger organisation. By finding means to enhance these through for example individual discussion and focussed team building, and organisational development interventions, the climate will become more positive and constructive.

\section{REFERENCES}

Antonovsky, A. (1979). Health, stress and coping: New perspectives on mental and physical well-being. San Francisco: Jossey-Bass.

Antonovsky, A. (1984). A call for a new question - salutogenesis and a proposed answer - the sense of coherence. Journal of Preventative Psychiatry, 22(1), 1-11.

Antonovsky, A. (1987a). Unravelling the mystery of health. How people manage stress and stay well. San Francisco: Jossey-Bass Publishers.

Antonovsky, A. (1987b). Health promoting factors at work: The sense of coherence. In Kamilo, R. Eltatawi, M. \& Cooper, C. (Eds), Psychosocial Factors at Work and their effects on Health, World Health Organisation, WHO, Geneva, 153167.

Antonovsky, A. (1988). Family sense of coherence and family adaptation. Journal of Marriage and the Family, 50, 79-92.

Antonovsky, A. (1993). The structure and properties of the sense of coherence scale. Social Sciences Medical Journal, $36(6), 725-733$.

Auhagen, A. (2000). On the psychology of meaning of life. Swiss Journal of Psychology, 59(1), 34-48.

Babin, B.J. \& Boles, J.S. (1996). The effects of perceived co-worker involvement and supervisor support on service provider role stress, performance and job satisfaction. Journal of Retailing, 72(1), 57-75.

Ballantine, K., Nunns, C.G. \& Brown, S. (1992). Development of the Goal Setting Support Scale GSSS: Subordinate assessment of supervisory support in the goal-setting process. South African Journal of Psychology, 22(4), 208-214.

Bandura, A. (1982). Self-efficacy mechanism in human agency. The American Psychologist, 37(2), 122-147.

Bandura, A. (1989). Human agency in Social Cognitive theory. American Psychologist, 44(9), 1175-1184.

Bandura, A. (1997). Self Efficacy: The exercise of control. New York: W.H. Freeman.

Bandura, A. \& Wood, R. (1989). Effect of perceived controllability and performance standards on self-regulation of complex decision making. Journal of Personality and Social Psychology, 56(5), 805-814.

Barling, J. \& Beattie, R. (1983). Self-efficacy beliefs and sales performance. Journal of Organisational Behaviour Management, $5,41-51$.

Burke, W.W. \& Litwin, G.H. (1992). A causal model of organisation performance and change. Journal of Management, 18(3), 523-545.

Carrol, J.S. \& Tosi, H.J. (1970). Goal characteristics and personality factors in a management by objectives program. $A d-$ ministrative Science Quarterly, 15, 295-304.

Chiles, A. \& Zorn, T. (1995). Empowerment in organisations: Employee's perceptins of the influences on empowerment. Journal of Applied Communication Research, 23(1), 1-25.

Collins, B.E., Davis, H.L., Myers, J.G. \& Silk, A.J. (1964). An experimental study of reinforcement and participant satisfaction. Journal of Abnormal and Social Psychology, 68, 463467.

Constable J.F. \& Russell, D.W. (1986). The effect of social support and the work environment upon burnout among nurses. Journal of Human Stress, 12(1), 20-26.

Cooper, C.L. \& Payne, R. (1991). Personality and Stress: Individual differences in the stress process. New York: Wiley.

Cummins, R.C. (1989). Locus of control and social support.
Clarifiers of the relationship between job stress and job satisfaction. Journal of Applied Social Psychology, 19, (9), 772778.

Day, D.V. \& Bedeian, A.G. (1991). Predicting job performance across organisations: The interaction of work orientation and psychological climate. Journal of Management, 17(3), 589-600.

Drory, Y. \& Florian, V. (1998). Sense of coherence and mental health profile in forst myocardial infraction patients. Magamot, 39, (1-2), 116-127

Erwee, R. \& Pottas, C.D. (1982). Locus of control and achievement motivation of managers. Psychologica Africana, 21, 79-102.

Feigin, R., Moshe, S. \& Abraham, O. (1996). Couples' adjustment to one partner's disability: The relationship between sense of coherence and adjustment. Social Science Medicine, 43(2), 163-171.

Feldt, T., Kinnunen,U. \& Mauno, S. (2000). A mediational model of sense of coherence in the work context: A oneyear follow-up study. Journal of Organizational Behavior, 21, 461-476.

Ferguson, E. (1993). Rotter's Locus of Control Scale: A tenitem two factor model. Psychological Reports, 73, 1267-1278.

Fiorelli, J. \& Margolis, H. (1993). Managing and understanding large systems change: Guidelines for executives and change agents. Organisation Development Journal, 11(3), 30-37.

Foley, J.R. \& Clifton, R.A. (1990). Locus of control, organisational climate, and participation in staff development: A study of college students. The Canadian Journal of Higher Education, 20(2), 45-59.

Garson, B.E. \& Stanwyck, D.J. (1997). Locus of Control and incentive in self managing teams. Human Resource Development Quarterly, 8(3), 247-258.

Gelfand, J. (1972). The modification, development and application of a measure of organisational climate and its relationship to higher order needs. Master's dissertation. Johannesburg: University of the Witwatersrand.

Gist, M.E. \& Mitchell, T.R. (1992). Self Efficacy: A theoretical analysis of its determinants and malleability. Academy of Management Review, 17(2), 183-211.

House, J.S. (1981). Work stress and social support. London: AddisonWesley.

Howell, D.C. (1989). Fundamental Statistics for the behavioural Sciences. Boston: PWS Kent.

Kirsch, I. (1986). Early research on self-efficacy: what we already know without knowing we knew. Journal of Social and Clinical Psychology, 4(3), 339-358.

Kline, T.J.B. \& Boyd, J.E. (1991). Organisational structure, context and climate: Their relationships to job satisfaction at three managerial levels. The Journal of General Psychology, 118(4), 305-316.

Kogan, M. (2001). Where happiness lies. Monitor on Psychology, 32(1), 74-76.

Kossuth, S.P. (1998). Team building and salutogenic orientations contextualised in a performance model. Doctoral thesis. Pretoria: University of South Africa.

Kottke, J. \& Sharafinski, C.E. (1988). Measuring perceived supervisory and organisational support. Educational and Psychological Measurement 48(4), 1075-1079.

Latham, G.P. \& Saari, L.M. (1979). The importance of supportive relationships in goal setting. Journal of Applied Psychology, 64, 151-156.

Lee, C. (1988). The effects of goal setting and monetary incentives on self-efficacy and performance. Journal of Business and Psychology, 2(4), 366-372.

Lewin, K. (1951). Field theory in social science. New York: Harper \& brothers.

Likert, R. (1961). New patterns of management. New York: McGraw-Hill.

Litwin, G.H. \& Stringer, R.A. (1968). Motivation and Organisation Climate. Cambridge: Graduate School of Business Administration, Harvard University.

Locke, E.A. \& Latham, G.P. (1984). Goal setting: A motivational technique that works. Englewood Cliffs: Prentice-Hall.

Locke, E.A., Shaw, K.N., Saari, L.M. \& Latham, G.P. (1981). Goal setting and task performance: 1969-1980. Psychological Bulletin, 90,125-152. 
Lyons, T.F. (1971). Role clarity, need for clarity, satisfaction, tension and withdrawal. Organisation Behaviour and Human Performance, 6, 99-110.

Nunnally, J.C. (1978). Psychometric Theory. (2nd ed.). New York: McGraw-Hill.

Payne, D.D. \& Manning, B.H. (1988). The effect of cognitive self-instructional strategies on preservice teachers' locus of control. Journal of Contemporary Educational Psychology, 13, 140-145.

Prakasam, R. (1986). Organisational climate: Development of a questionnaire measurement. Psychological Studies, 31(1), 51-55.

Pretorius, B.T. (1993). Commitment, participation in decisionmaking and social support: Direct and moderating effects on the stress burnout relationship within an educational setting. South African Journal of Psychology, 23(1), 10-14.

Robbins, S.P. (1998). Organizational behavior. Concepts, controversies, applications. Upper Sadle River: Pentice-Hall.

Rothmann, S. \& Agathagelou, A.M. (2000). Die verband tussen lokus van beheer en werkstevredenheid by senior polisiepersoneel. Journal of Industrial Psychology, 26(2), 20-26.

Rothmann, S. (2000). Sense of coherence, locus of control and self-efficacy and job satisfaction. Paper presented at the 28th International Congress of Psychology, Stockholm, Sweden.

Rotter, J.B. (1966). Generalised expectancies for internal versus external control of re-inforcement. Psychological Monographs, 80(1),1-28.

Rotter, J.B. (1975). Some problems and misconceptions related to the construct of internal vs external control of re-inforcement. Journal of Consulting and Clinical Psychology, 43(1), 56-67.

Rotter. J.B. (1990). Internal and external locus of control of reinforcement. American Psychological Association, 45(4), 489-493.

Ryland, E. \& Greenfeld,S. (1992). Work stress and wellbeing: An investigation of Antonovsky's Sense of Coherence model. Journal of Social Behaviour and Personality, 6(7), 39-54.

Sagy, S. \& Antonovsky, A. (1998). The family sense of coherence: The salutogenic approach. Magamot, 39(1-2), 80-96.

SAS. (1985). StatisticsVol, 1, Version 5. Cary, NC: SAS Institute Inc.

Schnyder, U., Büchi, S., Sensky, T. \& Klaghofer, R. (2000). Antonovsky's Sense of coherence: Trait or State? Psychotherapy and Psychosomatics, 69, 296-302.

Sorensen, R. \& Savage, G. (1989). Signalling participation through rational communication. A test of the leader interpersonal influence model. Group and Organisation Studies, 14(3), 325-354.

SPSS. (1994). SPSS Professional Statistics 6.1. Chicago: SPSS International.

Strümpfer, D.J.W. (1990). Salutogenesis: A new paradigm. South African Journal of Psychology, 20(4), 265-276.

Strümpfer, D.J.W. (1992). Psychological strengths as point of departure: Fortigenesis. Paper presented at the National Congress of the Psychological Society of South Africa, Stellenbosch.
Strümpfer, D.J.W. (1995). The origins of health and strength: From salutogenesis to "fortigenesis". South African Journal of Psychology, 25(2), 81-89.

Strümpfer, D.J.W. (1998). Sense of coherence and job satisfaction: review of South African data. Paper presented at the National Congress of the Psychological Society of South Africa, Cape Town.

Strümpfer, D.J.W. \& Wissing, M.P. (1999). Review of South African data on the sense of coherence scale as a measure of fortigenesis and salutogenesis. Paper presented at the National Congress of the Psychological Society of South Africa, Durban.

Sutherland, V.J. \& Cooper, C.L. (1990). Understanding stress: a psychological perspective for help professionals. London: Chapman \& Hall.

Taguiri, R. \& Litwin, G. (1968). Organisational climate: Exploration of a concept. Cambridge: Graduate School of Business Administration, Harvard University.

Taylor, M.S., Locke, E.A., Lee, C. \& Gist, M.E. (1984). Type A behaviour and faculty research productivity: What are the mechanisms. Journal of Organisational Behaviour and Human Performance, 34, 402-418.

Tipton, R.M. \& Worthington, E.L. (1984). The measurement of generalized self-efficacy: A study of construct validity. Journal of Personality Assessment, 48, 545-548.

Vance, R.J. \& Colella, A. (1990). Effects of two types of feedback on goal acceptance and personal goals. Journal of Applied Psychology, 75, 6-76.

Viviers, A.M. (1996). Salutogenese in organisatoriese konteks. Doctoral thesis. Pretoria: University of South Africa.

Viviers, A.M. (1999). Die persoonlikheidsoriëntasieprofiel van die salutogenies-funksionerende mens. Journal of Industrial Psychology, 25(1), 21-26.

Wissing, M.P. \& Van Eeden, C. (1994). Psychological wellbeing: Measurement and construct clarification. Paper presented at the 23rd International Congress of Applied Psychology, Madrid.

Wissing, M.P. \& Van Eeden, E. (1997a). Facing the challenge to explicate mental health salutogenically: Sense of coherence and $p s y$ chological well-being. Paper presented at the 55th Annual Convention of the International Council of Psychology, Graz.

Wissing, M.P. \& Van Eeden, E. (1997b). Psychological well-being: A fortigenic conceptualisation and empirical clarification. Paper presented at the National Congress of the Psychological Society of South Africa, Durban.

Watkins, M.L. \& Mauer, K.F. (1994). The performance values of white and black managers in South Africa. South African Journal of Psychology, 24(2).

Winnbust, J.A.M., Marcelissen, F.H.G. \& Kleber, R.J. (1982). Effects of social support in the stress-strain relationship: A Dutch Sample. Social Science and Medicine, 16, 475-482.

Wood, R. \& Bandura, A. (1989). Social cognitive theory of organisational management. Academy of Management Review, 14(3), 361-384 